The definitive version of this article is available at http://www.sagepublications.com/

Published as: Belchior Ana M. and Freire A.(2013) Is Party Type Relevant to an Explanation of Policy Congruence? Catch-all versus Ideological Parties in the Portuguese Case. International Political Science Review 34(3): 273-288 DOI: http://dx.doi.org/10.1177/0192512112467215 


\title{
Is Party Type Relevant to an Explanation of Policy Congruence? Catch-all versus Ideological Parties in the Portuguese Case
}

Ana Maria Belchior

André Freire

\begin{abstract}
Most research on political congruence has failed to address a fundamental aspect: the explanation of its causality. Party characteristics are acknowledged to be relevant, but there is no consensus as to their effective importance. Nor has there thus far been an analysis of the implications for results of using different methods to assess congruence. The present article seeks to respond to these goals by testing the importance of party type (catch-all versus ideological) to an explanation of levels of intra-party congruence, comparing the main methods of assessing congruence. The study focuses on the Portuguese party system and makes use of a set of 14 policy issues across two dimensions: socioeconomic left-right and libertarian-authoritarian (plus left-right selfplacement).
\end{abstract}

Findings support the notion that Portuguese catch-all parties tend to display slightly higher levels of MP-voter congruence than more ideological parties, although that is essentially dependent on the issue in question. These results were supported by the different methods used (albeit to a lesser extent by centrism).

Keywords: party type, issue congruence, policy preferences, Portugal. 


\section{Introduction}

In Western European parliamentary democracies parties are not only fundamental actors in the democratic process, but also the key official channels that connect the will of the people to their representation in parliament; and the link provided by elections serves as a basis on which to assess voter-MP congruence (Dalton, 1985: 278; Powell, 2000: 5; McDonald and Budge, 2005). Political parties are thus central to a study of representation. However, research has rarely focused on political parties' specificities as independent variables in an explanation of policy congruence.

Although a number of studies on political congruence have looked at its causality (e.g. Huber and Powell, 1994; Dalton, 1985; Holmberg, 2000), and even the importance of the characteristics of political parties, there is an aspect that has not been widely explored - the relevance of the type of party to this explanation. In particular, the investigation of the congruence produced by different types of party has not yet generated a very clear picture and has led to contradictory results: some research has stated that catch-all parties are more congruent than ideological ones (Przeworski and Sprague, 1986; Iversen, 1994; Holmberg, 1989. 2000); other authors have argued that the opposite is true (Dalton, 1985:188-295; Klingemann, 1995; Pierce, 1999: 27-30). Our aim is therefore to assess which of these two conflicting perspective is the most adequate (if any) using the Portuguese party system as the case study.

Furthermore, studies on Portuguese MP-voter linkages have pointed to greater congruence in catch-all parties compared to the most ideological parties (Belchior, 2008) but no clear pattern has emerged (only a few significant research projects have thus far addressed the policy congruence of Portuguese parties - exceptions are Belchior, 2008 and 2010). These mixed results underlie a fundamental question: are results conditioned by the measures that are used? And thus if one were to use different 
measures, would different results be found? Golder and Stramski consider that the choice of a certain conceptualization of congruence strongly conditions results (2010: 90-6). In order to test this assumption we propose to study the level of MP-voter congruence within political parties, using a set of measures of congruence that cover the most important methodological perspectives of the measurement of congruence. Besides aiming to contribute to a better understanding of the importance of party type to an explanation of levels of MP-voter congruence, the findings of this research are also expected to contribute to an improved understanding of the importance of using different measures for the study of policy congruence.

Moreover, in studying the Portuguese case we are able to rely on high quality data (a survey of MPs and a representative mass survey of Portuguese citizens) that use extensive batteries of questions of socioeconomic left-right issues and libertarianauthoritarian issues, as well as left-right self-placement. Based on the relevant literature about the socioeconomic left-right and the authoritarian-libertarian divides (see for example Knutsen, 1997; Freire 2008; Flanagan and Lee, 2003), the policy preferences are organized in the analysis into two major dimensions: socioeconomic left-right issues, and libertarian-authoritarian issues. We use 14 items that measure policy preferences - seven to measure the traditional economic (left-right) dimension and another seven to measure the libertarian-authoritarian dimension, plus left-right selfplacement. This option allows us to introduce a degree of control for the kind of issue at stake: traditional socioeconomic versus new politics issues. Using different measures and different policy issues, we want to assess if the type of party is indeed a relevant variable regarding voters-MPs level of congruence.

Our analysis focuses on the five parties that currently have seats in the Portuguese Parliament. The configuration of the Portuguese party system was 
established soon after the Revolution of 25 April 1974. The centre-left Socialist Party (PS - Partido Socialista, founded in 1973) and the center-right Social Democratic Party (PPD/PSD - Partido Social Democrata, founded in 1974) immediately became the country's largest parties. They are commonly considered catch-all parties (e.g. Lopes, 2004, 122) and have been alternating in government (either alone or in coalition) since 1976. With a few one-off exceptions, the tendency has been for voting to be concentrated in these two centrist parties, especially after 1987, since when they have together consistently received $70 \%$ of votes (with a slight fall since the 2009 national elections) (Lobo, 1996; Freire, 2005).

To the right of the PPD/PSD is the Democratic Social Centre/Popular Party (CDS/PP - Partido do Centro Democrático e Social/Partido Popular). Closest to the cadre party type (e.g. Lopes, 2004, 33, 36-8), it represents mainly Christian-democrat values and conservative voters. Despite its small size in electoral terms (usually below $10 \%$ ), the CDS/PP has managed to present itself as a party with the potential to form part of government coalitions, and has been included as such in government on a number of occasions.

The Portuguese Communist Party (PCP - Partido Comunista Português) is a Marxist-Leninist party. Founded in 1921, it is the only political group that resisted the major adversities of the dictatorship period and a concomitantly clandestine existence. It was (and is) therefore the oldest active Portuguese party, and the only one that can properly be considered a mass party (e.g. Lopes, 2004, 79). Since 1987, the PCP has always stood for election in coalition (CDU - Coligação Democrática Unitária) with the Greens (PEV - Partido Ecologista Os Verdes). Its electoral results have experienced a continuous fall, to slightly below $8 \%$ in the most recent elections (2011). 
Finally, the Left Block (BE - Bloco de Esquerda) - the most recent party to emerge in the Portuguese Parliament (in 1999) - is a left-libertarian party. Its electoral representativity was initially very low, with percentages of around $2 \%$, but has grown, albeit never attaining $10 \%$. In the recent elections in 2011, it fell back to around 5\%.

In a wide diversity of parties and party typologies (see Gunther and Diamond, 2003), the dichotomy between catch-all and ideological parties is a simple classification supported mainly by parties' electoral strategies and ideological profile. As an ideal type, catch-all parties are more electorally oriented, pluralistic, and distinguished by a shallow organization and a vague ideology (center-oriented). Ideological parties have more consistent and coherent programmatic or ideological agenda, and their issue appeals are less diffuse and eclectic than those of catch-all parties. Unlike the catch-all type, their electoral strategy is not to short-term maximize votes, win elections and govern, but rather to mobilize their core constituency and mold opinions and expand votes in the long term (Gunther and Diamond, 2003: 185-7). In our research the PS and PPD/PSD are considered catch-all parties, while the CDS/PP (on the right), CDU and $\mathrm{BE}$ (on the left) are taken to be ideological parties.

We begin with a presentation of the most relevant literature on the topic, and then discuss the different approaches to the measurement of congruence and present the analytical methods and data sources. Finally, we analyze and discuss the empirical findings.

\section{On Policy Congruence and Party Type}

To many democratic theorists, congruence is an important characteristic that ought to be encouraged - democratic governments are supposed to reflect the interests of their citizens (e.g. Pitkin 1967; Dahl 2006 (1956)). However, it is broadly recognized that the 
empirical implementation of straightforward MP-voter congruence is impracticable (Pierce, 1999: 25; Thomassen and Schmitt, 1999: 186), and it should not be understood as the legitimate vision of democratic representation (e.g. Thomassen, 1994: 238, 2578). Furthermore, congruence should not be seen as directly connected to the quality of democracy, or of a better representation of voters' interests. Instead, it should be seen as an indicator, among others, that contribute to the understanding of the representation process.

The main conclusion from research on MP-voter congruence is that it is extremely difficult to identify a clear tendency or pattern. Some authors argue that congruence tends to be low (Thomassen, 1994; Miller et al., 1999; Pierce, 1999); while others say there is evidence that policymakers follow public preferences more often than not (Erikson et al., 2002: Chap. 8; Manza and Lomax, 2002; Kang and Powell, 2010). Above all, it seems that congruence varies a lot, especially depending on the issue at stake (Dalton, 1985: 380; Thomassen, 1994: 255; Thomassen, 1999: 45-52; Thomassen and Schmitt, 1999: 199; Manza and Lomax, 2002). It has been demonstrated to be greater for ideological or highly politicized issues (Dalton, 1985: 283; Thomassen, 1994: 254-6. 1999: 53; Holmberg, 2000: 163-5; Mattila and Raunio, 2006: 437-9), especially with regard to an "ideological super-issue", such as the left-right dimension in the case of most European countries (Pierce, 1999: 30).

Although it is evident that parties' characteristics influence the connection they establish with their electorates, the nature of the relationship has not been entirely clarified. There is some - more or less deductive - theory on the importance of the type of party on the levels of congruence that are produced, but the empirical support for this assumption is limited. The existing literature allows us to advance two main (albeit antagonical) perspectives, although there is also other research which admits that it may 
actually be impossible to reach any conclusion on the nature of the relationship between party type (catch-all versus ideological) and the level of party-voter congruence (Dalton, 1985: 288-91). On the one hand, it is suggested that larger, centrist parties (such as catch-all parties) produce less congruence with their electorate than smaller, ideologically more polarized ones. This view is justified by the fact that the former seek to diffusely reach the median voter, while the latter, because they do not share the same strategy for gaining power, tend to position themselves in a way that better matches the desires of the segments of the electorate they represent (see Dalton 1985: 290-2; Klingemann 1995: 197-8). On the other hand, a competing explanation postulates that parties situated in the center are more congruent than more ideological parties. Here, the justification rests on this type of party's strategy in relation to the position taken by public opinion: if the idea is to change public opinion while accepting that the vote will not be maximized in the short term - said to be the tendency among more ideological parties - then the congruence such parties produce will necessarily be smaller. However, if the strategy is to captivate public opinion and maximize social mobilization in the short term, then a party must move towards that opinion - something that proponents of this view suggest is especially the case with parties that are oriented towards the ideological center. To the extent that they aspire to power, such parties promote concordance with the "median voter" (see Przeworski and Sprague 1986; Iversen 1994, Holmberg 1989. 2000). In this case, catch-all parties would tend to display higher levels of correspondence than ideological parties since, unlike the latter, they would not try to change the views of the electorate (see also Holmberg, 1989: 12; Iversen, 1994b: 160, 173-7, 181-3).

Indeed, in proportional electoral systems such as the Portuguese, opposing demands seem to be simultaneously at play in each of these types of party. If catch-all 
parties aim at strategically maximizing votes in the short term, directing their efforts to the median voter, it might produce higher congruence since these parties try to converge with voters in order to get more votes. But it can also produce lower levels of congruence given that they are trying to reach a politically widespread and heterogeneous electorate. The opposite is expected to happen with ideological parties: they also aim at gaining as many votes as they can, but since their agenda is more focused on specific issues with which they want to strategically reach some segments of the electorate, it suggests that higher level of congruence might be generated. But at the same time they tend to adopt more radical views, and that might be related to lower congruence since voters tend to be more moderate in their ideological positions than parties (Belchior, 2010). Indeed, the mere fact that voters are more centrist than parties is a strong point to expect that, disregarding party electoral strategies, the more centrist parties (catch-all) display better results concerning congruence with voters.

Since, as stated above, the levels of party congruence especially vary according to the issue at stake, the importance of party type in explaining congruence must be controlled for the kind of policy issue. To assess it we compare old socioeconomic leftright issues (more ideological and politicized), with new authoritarian-libertarian issues (less ideological and politicized). Catch-all parties are expected to especially explore the most politically salient and mobilizing issues in order to pursue their vote maximization strategy. Therefore, we would expect catch-all parties to be more congruent specifically regarding the traditional left-right issues, when compared to ideological parties.

It is also our intent to control both party type and policy issue for the measures of congruence: does the level of congruence vary across parties and issues as we use different measures of congruence? Our expectation in this regard is that relative measures of congruence, given that they control for voters' variance, are expected to 
lower the level of congruence in catch-all parties (since they want to reach the median voter that is spread along the ideological center). The same is not expected to happen in ideological parties, because in these parties voters' variance tends to be comparatively lower.

\section{Methods and Data}

Since Achen (1978) and until Golder and Stramski (2010), the biggest issue regarding how collective congruence ought to be measured seems to have been whether to use relative or absolute measures. There are several plausible ways to conceptualize and measure congruence, each of which might potentially lead to quite different results. For example, conceptualizing congruence simply in terms of the distance between citizens and their representatives (absolute congruence) can rank citizen-representative congruence very differently from ways that also take account of the dispersion in citizens' preferences (relative congruence). This suggests that empirical results with regard to citizen-representative congruence may well depend on the particular forms of conceptualization and measuring adopted. Empirical analysis has consequently been ranging between these two ways of measuring congruence. Absolute congruence has the advantage that calculations are simple and the interpretation of results is intuitive. Relative congruence is generally better in terms of the validity of the measurements, since it takes into account voters' dispersion. This way it is possible to control for voters' distributions within parties, and to better compare congruence across parties. The goal of the present research is to use both measures in order to consolidate results. ${ }^{1}$

Congruence occurs if the elected MPs share the ideological positioning of the citizens who voted for them. We use measures of collective representation to measure this, comparing MPs' party groups with their respective voter groups (as per e.g. 
Dalton, 1985; Holmberg, 1989; Belchior, 2008. 2010). In terms of its measurement, the different ways of operationalizing congruence can conceivably lead to quite different rankings of the same set of representatives. Indeed, one controversial aspect of the study of congruence has been the information that can be extracted from different ways of operationalizing congruence. As such, the kind of operationalization used can be relevant to (if not determinant for) the results obtained. We expect this relevance to be higher concerning catch-all parties.

In order to summarize the measures used in the analysis, Figure 1 shows the four we employ for each of the two approaches - absolute and relative - to the measurement of congruence: from the measure that is simplest and with lower validity, to the more complex and with higher validity.

Figure 1. Measure of collective congruence: a synthesis (ABOUT HERE)

We first explore the percentages of agreement and differences between MPs and voters, which is the most straightforward measure of absolute congruence. It allows us a general picture of intra-party consonance regarding policy issues.

To measure absolute congruence we also use Holmberg's means difference measure (1989: 13-23. 2000), which represents the average divergence between MPs and voters positions regarding policy issues (MPs minus voters). Because variables are measured on a five-point scale, the means difference measure can vary between 0 (perfect congruence) and 4 (maximum incongruence). Since it has support in the mean calculus, it provides a more synthetic picture of congruence, although it suffers from the major difficulty that it introduces bias if the distribution has outliers.

We assume that a concept of relative congruence is more appropriate than a concept of absolute congruence if one is interested in how well representatives are 
performing in terms of producing congruence. Absolute congruence is not the most appropriate if we are interested in comparing the relative performance of representatives across different parties, as is here the case. In this approach, which is inspired by Converse and Pierce (1986: 963-4), the standardized mean differences between MPs and their voters' policy issue positions is computed by dividing the differences (MPs minus voters) by the standard deviation of voter distributions. The measure is computed at the party level: for each party / policy issue. This measure disregards the signs of mean differences, since it is the distance between means and not the direction that is relevant to the analysis. Moreover, retaining the signs of the values would lead to situations in which different signs would cancel each other out, thereby erasing the true distance between the two positions. The lower the values of the standardized mean differences, the higher the congruence.

When considering congruence measurement problems, Achen - a reference in the study of this topic - devised forms of statistical measurement that cover different dimensions of the concept (1978: 483-4, 487-8). Of these, centrism is the strongest measure for assessing how closely the opinions of party elites mirror the views of their average (or median) supporters (see e.g. Dalton, 1985: 286). Noting the exceptionality of Achen's centrism with regard to the conceptualization of congruence, Golder and Stramski also asserted that "by normalizing congruence relative to the dispersion of citizen preferences, relative citizen congruence avoids the use of an abstract left-right scale and provides a metric free concept of congruence" (2010: 94). Centrism is thus considered the strongest measure for overcoming the potential comparability problems between MPs and voters.

Centrism measures how representatives actually represent the political preferences of their mean or median voter. It is measured by the difference between the 
proximity and the variance with regard to the position of the electorate. Proximity relates to the similarity of the party's position to that of its voters. That is:

$$
\hat{S} \mathrm{j}=\sum(a \mathrm{aij}-\mathrm{rj})^{2} / \mathrm{nj}
$$

where aij is the position of voter $a i$ in party $j, r j$ the mean position of the elite in that party, and $n j$ the size of the sample. And,

$$
\hat{Y} j^{2}=\sum(a i j-\bar{a} j)^{2} /(n j-1)
$$

measures the variance for the electorate, where $\bar{a} j$ is the median position of the voters; and

$$
\hat{C} j=\hat{S} j-\hat{Y} j^{2}
$$

is the measure of the centrism in party $j$. As in the previous measure and for the same reasons, for centrism we also disregard the signs and therefore all values become positive. High centrism values indicate a mismatch between the voters and the elite; low values indicate the reverse. ${ }^{2}$

More than assessing the levels of congruence of catch-all versus ideological parties across a set of 14 items, it is also our aim to assess whether the traditional/old politics issues characterizing the left-right divide produce more or less congruence than the new politics issues related to the libertarian-authoritarian divide, and if the kind of issues is more relevant than party type to explain congruence ${ }^{3}$. For this purpose we have two sets of variables, based on a question on policy agreement (5-point scale) ${ }^{4}$ : one dimension includes the traditional socioeconomic (left-right) issues; the other includes 
issues related to the libertarian-authoritarian dimension of competition. The first particularly concerns: state intervention in economy and society; fighting inequalities; or defending public education and health (for a review of the literature see e.g. Knutsen, 1997 and Freire, 2008). The libertarian-authoritarian dimension concerns, for example: lifestyle issues (abortion, same-sex marriage, etc.), and attitudes towards authority, immigration and environmental protection (see e.g. Flanagan and Lee, 2003; Kitschelt and Rehm, 2004). ${ }^{5}$

Due to its importance in structuring the political debate in most European countries, it is expected that the socioeconomic issues anchored in the left-right dimension will produce higher levels of MP-voter congruence than libertarianauthoritarian issues (Pierce, 1999: 27-9; Holmberg, 2000: 163-5).

As we briefly mentioned above, the data analysis is supported by two surveys conducted in Portugal in 2008, as part of the project "The Portuguese MPs in comparative perspective: elections, leadership, and representation" (see further references in Freire, Viegas and Seiceira, 2009). One is based on a multi-stage probability sample of Portuguese aged 18 or more and living on the mainland $(\mathrm{N}=1350)$. The other survey was aimed at the universe of the Members of Parliament (Assembleia da República) in office in the $10^{\text {th }}$ legislature (2005-2009), and also used face-to-face interviews. Out of a universe of 230 MPs, 141 responses were validated, giving a quite remarkable rate of response to surveys of representatives (61\%). An equivalent questionnaire covering basically the same topics was used for both the Portuguese citizens and the MPs.

The sample size - especially for MPs - is not always as big as we would like it to be, especially in the smaller parties. ${ }^{6}$ This is, however, a recurrent problem in these kinds of study since it requires equivalent questions for both groups: MPs and voters. 
Even acknowledging this, we consider that the effective sample sizes are good enough to reliably support our analysis.

\section{Findings}

We begin the analysis by presenting the results for the measures of absolute congruence - i.e. the percentages of policy agreement and mean policy agreement, and the differences for policy agreement between MPs and voters. Table 1 and 2 provide the percentages of policy agreement across the two dimensions and the five political parties.

Table 1. Policy agreement between voters and MPs on the socioeconomic left-right dimension $(\%)($ ABOUT HERE)

Table 2. Policy agreement between voters and MPs on the libertarian-authoritarian dimension $(\%)($ ABOUT HERE)

Looking at the values in Table 1 that summarize the average differences between parties considering the socio-economic left-right issues, we see that the PS displays the smallest average distance to its voters for the policies as a whole - a finding that matches expectations for catch-all parties. However, the other catch-all party, the PPD/PSD, does not share this privileged position of correspondence to its voters. The PPD/PSD's performance is bettered by that of the parties on the radical left (ideological) - the BE and CDU. As we would expect, the CDS (also considered ideological) appears in the position that is least privileged with regard to congruence with voters: on average there is a distance of more than $30 \%$ from the voters' position.

Although evidencing very similar distributions in terms of policy preferences, the Portuguese catch-all parties show two remarkable exceptions concerning public 
education and health issues. Voters from both parties and PS MPs tend to overwhelmingly agree that the state should play a major role in education and health i.e. they share a leftist position on this issue. However, the PPD/PSD MPs are significantly less supportive of state intervention than voters, especially with regard to education, thereby evidencing a clear right-wing stand. On average, the PS exhibits the best level of congruence among the Portuguese parties for socioeconomic issues. A similar pattern was found for MP-voter left-right self-placement (Freire and Belchior, 2009).

By and large it can be said that MPs and voters are coherent with and match the choice of policies connected with their parties' left-right placement, especially in the case of those on the left. However, the Portuguese electorate clearly tends to the socioeconomic left, even among those who identify with right-wing parties; and this explains most of the voter-MP incongruence that we can find on the right (for both catch-all and ideological parties).

In Table 2 the same analysis can be seen for the libertarian-authoritarian divide. In this case the smaller distance between MPs from catch-all parties and their voters is more evident in relative terms. The PS and the PPD/PSD both return lower average percentages for distance than the other parties, with the differences between the two of them essentially derived from the PS MPs' more libertarian position compared to that of the PPD/PSD MPs. However, there are greater differences in policy preferences (between MPs and voters for both types of parties) in this dimension than in the preceding one (left-right), which supports the theoretical expectations of ideological or highly politicized issues generating higher congruence.

Voters are in general significantly more authoritarian than MPs (except for the conservative party). This is the main reason for incongruence in this dimension across 
the left-wing parties, whose MPs are more libertarian than those of right-wing parties, especially in the ideological parties (BE and CDU).

In general, the analysis of percentages of agreement reveals that MPs tend to be more to the left and are more libertarian than their voters, disregarding the party type. From this analysis, although it seems that the Portuguese catch-all parties tend in general to be closer to their voters than the ideological parties, the truth is that no clear pattern emerges that would make it possible to validate the assumption that the former reflect voters' preferences better than the latter. In overall terms, this question varies greatly depending on the issue at stake, suggesting that it is essentially the policy issue (and not the party type) that contributes to explain party congruence.

Figure 2. Mean distances between MPs and voters referring to left-right policy issues (ABOUT HERE)

The measurement of the average distances between the positionings of MPs and those of voters shows that for the set of representations shown in Figure 2, on traditional economic left-right policy issues, it is again especially the socialist party that most often displays smaller average distances from its electorate. Although on some political issues the PPD/PSD also reveals small distances, the representations nonetheless do not allow us to conclude that the catch-all parties display better results in the analysis of the average distances. If we look at the set of ideological parties, performances vary depending on the policy issues and the particular party.

In short, where left-right issues are concerned and as we have already concluded, the catch-all parties - particularly the socialist party - tend to present their MPs as having average positions that are close to those of their electorates, although this does not represent a pattern; for various issues it is the ideological parties that are the most congruent. 
Figure 3. Mean distances between MPs and voters referring to libertarian-authoritarian policy issues (ABOUT HERE)

Turning to the libertarian-authoritarian dimension, the most immediate conclusion to be drawn from the representations in Figure 3 is the confirmation that, in terms of average distances, the MPs of all the parties reveal that they opt for more liberal positions (except the conservatives on some issues, and the PPD/PSD in a lesser extent in the case of abortion). In a way that is a little more evident than it was in the previous dimension, in most of the libertarian-authoritarian policy issues the PS and the PPD/PSD seem to be among those closest to their electorate.

Figure 5 gives a summary of the absolute measures of congruence analyzed above (the average point in the scale has been eliminated in order to emphasize the importance of the actors' ideological commitment), with the values of the average differences for each party represented for each of the two dimensions ${ }^{7}$. The catch-all parties occupy the position of the parties with the best performance, considering the two dimensions as a whole (also supported by Figure 4, regarding self-positioning on the left-right scale, in this case with CDS/PP). While the incongruence at the level of the libertarian-authoritarian dimension is greater on the left, on the right the incongruence is greater in the left-right dimension. This is a pertinent finding if we bear in mind that on the left the political struggle is essentially supported by economic and social issues linked to the left-right dimension, while on the right moral and lifestyle issues related to the libertarian-authoritarian dimension are more significant than they are in the parties on the left.

In conclusion, the catch-all parties tend to present better results for absolute congruence with their electorates, compared to the ideological parties, but it is the 
policy issue that best explains party congruence: voters tend to be more conservative than MPs regarding life-style and morally charged issues, and more left-oriented regarding the traditional economic and social issues. As a consequence, it is not party type, but the policy issue that better explains congruence: which is higher for left-wing parties concerning left-right issues, and for right-wing parties concerning libertarianauthoritarian issues. Additionally, the expectation that catch-all parties respond better to left-right than to libertarian-authoritarian issues is fulfilled.

Figure 4. Mean distances between MPs and voters referring to left-right self-positioning (ABOUT HERE)

Figure 5. Means difference (dichotomous variable) across policy dimensions (the mean of means) (ABOUT HERE)

Another conclusion from the data is that MPs tend to be to the left of their voters (Figure 4 for left-right self-placement, and Figure 3 for libertarian-authoritarian issues), especially in the case of left-wing parties. That elites position themselves further to the left than their voters (or further to the right for the more extreme right-wing parties) is not a new conclusion (see: Dalton, 1985; Converse and Pierce, 1986: 128; Holmberg, 1989: 19-23; Thomassen, 1999: 46-50; 2000: 167-9; Iversen, 1994: 168-75; Esaiasson and Holmberg, 1996: 92-5; Thomassen, 1999: 46-50; Belchior, 2008. 2010). In fact, and as postulated by Rabinowitz and MacDonald's directional model, voters generally seem to look for the party that offers the most intense alternative that matches their own preferred political views (Rabinowitz et al., 2003; Valen and Narud, 2007: 300). Another reason may simply be that voters prefer more central positions than MPs, across parties. As previous research has demonstrated, voters' ideologically more 
centered positions can potentially be explained by citizens having lower levels of ideological sophistication than elites (see e.g. Converse and Pierce, 1986, chap. 7).

We will now turn to the measures of relative congruence, which are supposed to be more accurate than absolute measures, inasmuch as they control for the variance of electorates. Table 3 and Figure 6 present the standardized mean differences for the policy issues in both dimensions and for left-right placement.

Table 3. Standardized mean differences across policy issues (ABOUT HERE)

Figure 6. Standardized mean differences across policy dimensions (the mean of means) (ABOUT HERE)

Although it varies depending on the issue at stake, when controlling the variance within parties, the PS and the PPD/PSD usually tend to be among the most congruent parties. Summarizing the information in Table 3, Figure 6 is especially illuminating by presenting the mean results for each dimension and across parties. Albeit supported by a different measure than the preceding Figure 5, it displays a remarkably similar representation. This means that the control for party-voter variance does not seem to significantly change the MP-voter congruence results. Taken together, the catch-all parties present the best performances, considering both dimensions simultaneously. In general it is possible to confirm that the left-wing parties perform better in the left-right dimension and the right-wing parties perform better in the libertarian-authoritarian dimension. Party type can be relevant, but both a party's left-right position and the kind of issue are as important, or even more so.

Although it controls for variance, the standardized mean differences does that at the party level - i.e. it does not consider each voter's distance to the median voter in the party individually, as centrism does, but rather voters' standard deviation from the mean 
position of voters within parties. This is why centrism is considered to be a stronger measure of congruence (Dalton, 1985: 286; Golder and Stramski, 2010: 94). Our last measure - centrism - is thus our most demanding test.

Table 4. Centrism across policy issues (ABOUT HERE)

Figure 7. Centrism across policy dimensions (the mean of centrism) and political parties (ABOUT HERE)

Table 4 presents the values for centrism for each policy issue individually, while Figure 7 does so by party and dimension. Inasmuch as variance is controlled at the individual level, it is not surprising that the scenario for centrism differs somewhat from previous results. Left-right dimension incongruence continues to be higher in the rightwing parties, and libertarian-authoritarian dimension incongruence continues to be higher for left-wing parties. However, neither the catch-all parties are clearly the best for congruence in either dimension, nor they seem to perform better regarding the traditional left-right dimension.

In the case of the catch-all parties, given that their MPs tend to be ideologically more moderate than voters, the reason for incongruence appears to lie at the variance level: by agglomerating a significant mass of ideologically disperse voters, catch-all parties appear to achieve a good congruence with voters in average terms (which is what absolute measures do). However, if we consider the discrepancies within the electorate (by using relative measures), the degree of congruence falls significantly, inasmuch as those discrepancies are highlighted by centrism. That means that the catchall type of party only seems to have some advantage in corresponding to their voters' policy preferences if absolute measures are used. This might be due to the fact that by using these measures discrepancies in voters' distributions cancel each other 
emphasizing voters' tendency for being centrally positioned. This way, congruence is likely to occur in centrist parties. This effect disappears as we use a measure that controls for voters' variance and, so does congruence within these parties.

The control of voters' variance also reveals that catch-all parties do not appear to be associated with better congruence at the traditional left-right dimension, as we expected (only the PS has a better performance in this dimension, though worse than $\mathrm{BE})$. Voters' tendency to a left-ward positioning regarding traditional socioeconomic policy issues, as we have been observing, seem to be the explanation for such a result.

This measure still allows reiterating that left-right dimension produces higher congruence, but only in the left-wing parties. Right-wing parties perform better regarding the libertarian-authoritarian dimension. This suggests that the Portuguese left parties are not being able to correspond to voters' moral and life style policy preferences which were supposed to be a policy niche especially for new left parties such as BE. Those issues are being more efficiently assimilated by the centrist catch-all parties.

\section{Concluding remarks and discussion}

The central goal of this research was to compare the predictive relevance of party type (catch-all versus ideological) to an explanation of the level of MP-voter congruence within the Portuguese political parties. Concomitant to that first goal it was also our intention to control this relationship by using different measures of policy congruence. Using four different kinds of measure (from absolute / rough measures, to relative / more accurate ones), we compared the relevance of party type to an explanation of political congruence across a set of policy issues (socioeconomic left-right versus libertarian-authoritarian). Some similar results were obtained regardless of the measure 
in use. However, when the variance is accounted for (relative measures), especially at the individual level (centrism), some substantive differences were found.

When controlled by the kind of issue, catch-all parties' slight advantage in congruence performance is lowered, with a division between left-wing (more congruent in socioeconomic left-right issues) and right-wing (more congruent in libertarianauthoritarian issues) parties, regardless of party type. In terms of direction of policy preferences, the left-wing parties are more congruent than the right-wing ones in the left-right issues: they are more in tune with an electorate that is overwhelmingly leftist in terms of its socioeconomic policy preferences. The opposite is also true for the authoritarian-libertarian divide: the right-wing parties are clearly more in tune with a predominantly conservative/authoritarian electorate in issues related to authority, immigration, or alternative life-styles.

Because the electorate traditionally prefers to place itself in the center, more congruent catch-all parties would be an expectable result. This was what we observed when we used measures of absolute congruence. However, the control of variance with regard to voters' political preferences in the measures of relative congruence (especially centrism) showed that each of the Portuguese catch-all parties only managed to effectively perform better than the ideological parties in one of the dimensions: the PPD/PSD was the most congruent party for the issues in the libertarian-authoritarian dimension of competition, while the PS was one of the parties with the best performance in relation to the traditional socioeconomic issues of the left-right divide. One explanation for this may be that each of these dimensions contains issues which differentiate the ideological identities on the left and the right and which are politically communicated with differing degrees of efficacy: it seems that on the left it is the economic and social questions linked to the left-right dimension that are more effective, 
while on the right it is the moral and lifestyle-related issues tied to the libertarianauthoritarian dimension. This interpretation may also extend to the ideological parties on both the left and the right. The expectation that catch-all parties would do better concerning the most ideological and politicized issues is not, therefore, met.

The performances of the ideological parties also differ greatly depending on the party and on the issue/dimension. It has been suggested that a stronger ideological anchoring means that communist parties in particular tend to exhibit higher levels of congruence with the electorate they represent (Klingemann 1995, pp. 197-8). However, as in a previous study (Belchior, 2008), in the present case the Portuguese Communist Party does not support this assumption. Across all measures, the CDU is among the least congruent of all the parties, albeit in relation to some issues the level of MP-voter congruence is remarkable. Almost the same thing can be extrapolated to the other two ideological parties.

In addition, overall policy issues anchored in the left-right divide tend to produce higher levels of MP-voter congruence in the Portuguese political parties than policy issues anchored in the libertarian-authoritarian dimension. This is an unsurprising finding if we consider that left-right is a dimension that is powerful and more politicized when it comes to organizing individuals' political thought and behavior, and that new politics issues are still not all that relevant to an explanation of voting behavior in the Portuguese case (Freire, 2005). This picture is not the same for all parties and issues, however.

To sum up: using high quality data concerning the under-studied Portuguese case and controlling for policy issue and measures to assess policy congruence, it can be said that party type (catch-all versus ideological) is not that important to an explanation of policy congruence. When we control for the dispersion of voters' policy preferences, 
the slight importance that was found for catch-all parties using relative measures of congruence tends to vanish. This finding underscores the importance of using alternative measures of policy congruence: catch-all parties are more congruent in absolute terms, but their constituencies are also more heterogeneous; once we control for this heterogeneity, the higher levels of congruence in catch-all parties is greatly reduced. Additionally, both the type of issue at stake (socioeconomic left-right versus new politics) and the location of parties in the left-right spectrum revealed to be important to explain MP-voter policy congruence. They are in fact more important than party type, because they continue to exist across different measures of congruence (absolute versus relative).

Finally, what we still don't know is whether these findings with regard to the Portuguese case are valid for other cases. Further efforts should thus be made with a view to achieving a better understanding of the relationship between party type, party location in the left-right spectrum, the type of issue at stake and MP-voter congruence. 


\section{References}

Achen C H (1978) Measuring Representation. American Journal of Political Science 22(3): 475-510.

Belchior A M (2008) Party Political Representation in Portugal. South European Society and Politics 13(4): 457-476.

Belchior A M (2010) Ideological Congruence among European Political Parties. Journal of Legislative Studies 16(1): 121-142.

Converse P and Pierce R (1986) Political Representation in France. Cambridge and London: The Belknap Press of Harvard University Press.

Dahl R (2006 (1956)) A Preface to Democratic Theory. Chicago and London: The University of Chicago Press.

Dalton R J (1985) Political Parties and Political Representation. Comparative Political Studies 18(3): 267-299.

Erikson R S, Mackuen M B and Stimson J A (2002) The Macro Policy. Cambridge: Cambridge University Press.

Esaiasson P and Holmberg S (1996) Representation from Above. Aldershot: Dartmouth. Flanagan S and Lee A-R (2003) The New Politics, Culture Wars, and the AuthoritarianLibertarian Value Change. Comparative Political Studies 36(3): 235-270.

Freire A (2005) Party System Change in Portugal, 1974-2005. Portuguese Journal of Social Science 4(2): 21-40.

Freire A (2008) Party Polarization and Citizens' Left-Right Orientations. Party Politics 14(2): 189-209.

Freire A, Viegas J M L and Seiceira F (orgs.) (2009) Representação Política em Portugal. Inquéritos e Bases de Dados. Lisbon: Sextante Editora. 
Golder M and Stramski J (2010) Ideological Congruence and Electoral Institutions. American Journal of Political Science 54(1): 90-106.

Gunther R and Diamond L (2003) Species of Political Parties. A New Typology. Party Politics 9(2): 167-199.

Holmberg S (1989) Political Representation in Sweden. Scandinavian Political Studies 12(1): 1-36.

Holmberg S (2000) Issue Agreement. In: Esaiasson P and Heider K (eds.) Beyond Westminster and Congress: the Nordic Experience. Columbus: Ohio State University Press, 155-180.

Huber J and Powell G B Jr (1994) Congruence between Citizens and Policy Makers in Two Visions of Liberal Democracy. World Politics 46(3): 291-326.

Iversen $T$ (1994) The Logics of Electoral Politics: Spatial, Directional, and Mobilizational Effects. Comparative Political Studies, 27(2): 155-189.

Kang S-G and Powell G B Jr (2010) Representation and Policy Responsiveness: The Median Voters, Election Rules, and Redistributive Welfare Spending. The Journal of Politics 72(4): 1014-1028.

Kitschelt H and Rehm P (2004) Socio-Economic Group Preferences and Party Alignments. In: $14^{\text {th }}$ International Conference of Europeanists, Chicago, USA, 11-13 March 2004.

Klingemann H-D (1995) Party positions and voter orientations. In Klingemann H-D and Fuchs D (eds) Citizens and the State. New York: Oxford University Press, pp.183-205.

Knutsen O (1997) The Partisan and the Value-Based Components of Left-Right SelfPlacement: a Comparative Study. International Political Science Review 18(2): $191-225$. 
Lobo M C (2001) The Role of Political Parties in Portuguese Democratic Consolidation. Party Politics 7(5): 643-653.

Lopes F F (2004) Os Partidos Políticos: Modelos e Realidades na Europa Ocidental e em Portugal. Lisbon: Celta Editora.

Manza J and Lomax F(2002) The Impact of Public Opinion on Public Policy: The State of The Debate. In Manza J, Cook F L and Page B (eds) Navigating Public Opinion: Polls, Policy, and the Future of American Democracy. New York: Oxford University Press, pp. 17-32.

Mattila M and Raunio T (2006) Cautious Voters. Supportive Parties: Opinion Congruence between Voters and Parties on the EU Dimension. European Union Politics 7(4): 427-449.

Miller W, Pierce R, Thomassen J, Herrera R, Holmberg S, Esaiasson P and Wessels B (1999) Policy Representation in Western Democracies. Oxford and New York: Oxford University Press.

Pierce R (1999) Mass-Elite Issue Linkages and the Responsible Party Model Representation. In Miller W, Pierce R, Thomassen J, Herrera R, Holmberg S, Esaiasson P and Wessels B (orgs) Policy Representation in Western Democracies. Oxford and New York: Oxford University Press, pp. 9-32.

Pitkin H F (1967) The Concept of Representation. Berkley, Los Angeles and London: University of California Press.

Przeworski A and Sprague J (1986) Paper Stones. A History of Electoral Socialism. Chicago: University of Chicago Press.

Powell G. B Jr (2000) Elections as Instruments of Democracy. New Haven and London: Yale University Press. 
Rabinowitz G, MacDonald S E and Listhaug O (2003) Issue Voting in a Responsible Party System. In: the annual meeting of the American Political Science Association, Philadelphia, USA, 27-31 August (at: http://www.allacademic.com//meta/p_mla_apa_research_citation/0/6/3/7/8/page s63784/p63784-1.php).

Thomassen J (1994) Empirical Research into Political Representation: Failing Democracy or Failing Models?. In: Jennings M K and Mann T E (eds) Elections at Home and Abroad. Ann Arbor: The University of Michigan Press, pp. 237-264. Thomassen J (1999) Political Communication between Political Elites and Mass Publics. The Role of Belief Systems. In Miller W, Pierce R, Thomassen J, Herrera R, Holmberg S, Esaiasson $\mathrm{P}$ and Wessels B (orgs) Policy Representation in Western Democracies. Oxford and New York: Oxford University Press, pp. 3358.

Thomassen J and Schmitt H (1999) Issue Congruence. In: Schmitt H and Thomassen J (eds) Political Representation and Legitimacy in the European Union. Oxford and New York: Oxford University Press, pp. 186-208.

Valen H and Narud H M (2007) The Conditional Party Mandate: a Model for the Study of Mass and Elite Opinion Patterns. European Journal of Political Research 46(3): 293-318. 


\section{Figure 1. Measures of collective congruence: a synthesis}

\begin{tabular}{lll}
\hline \multicolumn{1}{c}{ Measures } & \multicolumn{1}{c}{ Validity } \\
\hline $\begin{array}{l}\text { Percentage of agreement (and } \\
\text { differences) }\end{array}$ & Low (rough measure; little information) \\
\cline { 2 - 3 } Absolute congruence & $\begin{array}{l}\text { Means and means difference } \\
\text { measure }\end{array}$ & Low (biased in distributions with outliers) \\
\hline Relative congruence & $\begin{array}{l}\text { Standardized mean } \\
\text { differences }\end{array}$ & $\begin{array}{l}\text { High (controls for variance at the party level; bias can } \\
\text { still occur since the basis is the mean) }\end{array}$ \\
\cline { 2 - 3 } & Centrism & $\begin{array}{l}\text { High (controls for voters' variance; more accurate if } \\
\text { the median is used) }\end{array}$ \\
\hline
\end{tabular}


Table 1. Policy agreement between voters and MPs on the socioeconomic left-right dimension (\%)

\begin{tabular}{|c|c|c|c|c|c|c|c|c|c|c|c|c|c|c|c|}
\hline \multirow{2}{*}{ DIMENSION: Left-Right } & \multicolumn{3}{|c|}{$\mathbf{B E}$} & \multirow{2}{*}{\multicolumn{2}{|c|}{$\begin{array}{l}\text { CDU } \\
\text { MPs }\end{array}$}} & \multirow[b]{2}{*}{ Diff } & \multirow[b]{2}{*}{ Voters } & \multirow{2}{*}{$\begin{array}{c}\text { PS } \\
\text { MPs }\end{array}$} & \multirow[b]{2}{*}{ Diff } & \multirow[b]{2}{*}{ Voters } & \multirow{2}{*}{$\begin{array}{l}\text { PSD } \\
\text { MPs }\end{array}$} & \multirow[b]{2}{*}{ Diff } & \multirow[b]{2}{*}{ Voters } & \multirow{2}{*}{$\begin{array}{l}\text { CDS } \\
\text { MPs }\end{array}$} & \multirow[b]{2}{*}{ Diff } \\
\hline & Voters & MPs & Diff & & & & & & & & & & & & \\
\hline $\begin{array}{l}\text { "Politicians should abstain from } \\
\text { intervening in the economy" }\end{array}$ & 33.6 & 10.0 & 23.6 & 26.1 & 0.0 & 26.1 & 26.0 & 4.4 & 21.6 & 26.9 & 9.5 & 17.4 & 49.6 & 60.0 & 10.4 \\
\hline $\begin{array}{l}\text { "Providing a stable social security } \\
\text { network should be the prime goal of } \\
\text { government" }\end{array}$ & 96.5 & 100.0 & 3.5 & 97.6 & 67.4 & 30.2 & 92.8 & 87.5 & 5.3 & 91.4 & 90.0 & 1.4 & 72.2 & 83.3 & 11.1 \\
\hline $\begin{array}{l}\text { "Income and wealth should be } \\
\text { redistributed towards ordinary people" }\end{array}$ & 87.5 & 100.0 & 12.5 & 95.6 & 100.0 & 4.4 & 92.6 & 91.0 & 1.6 & 94.1 & 95.5 & 1.4 & 63.6 & 85.7 & 22.1 \\
\hline $\begin{array}{l}\text { "Education should mainly be provided by } \\
\text { the State" }\end{array}$ & 100 & 100.0 & 0.0 & 100.0 & 100.0 & 0.0 & 96.9 & 93.4 & 3.5 & 98.2 & 42.0 & 56.2 & 94.2 & 12.5 & 81.7 \\
\hline $\begin{array}{l}\text { "Healthcare should mainly be provided by } \\
\text { the State" }\end{array}$ & 96.9 & 100.0 & 3.1 & 99.1 & 100.0 & 0.9 & 97.8 & 98.9 & 1.1 & 97.5 & 59.9 & 37.6 & 88.1 & 50.0 & 38.1 \\
\hline $\begin{array}{l}\text { "The present levels of social protection } \\
\text { must be kept the same even if it means an } \\
\text { increase in taxes" }\end{array}$ & 54.7 & 100.0 & 45.3 & 75.3 & 83.3 & 8.0 & 68.5 & 90.2 & 21.7 & 58.7 & 68.5 & 9.8 & 14.8 & 28.6 & 13.8 \\
\hline $\begin{array}{l}\text { "Economic growth is more important than } \\
\text { balancing the state budget" }\end{array}$ & 76.8 & 100.0 & 23.2 & 92.0 & 100.0 & 8.0 & 88.9 & 67.9 & 21.0 & 91.3 & 95.7 & 4.4 & 100.0 & 57.1 & 42.9 \\
\hline Mean differences & & & 15.9 & & & 11.1 & & & 10.8 & & & 18.3 & & & 31.4 \\
\hline
\end{tabular}

Notes: Figures are the percentage of respondents who agreed (totally or partially) with the proposition, by party identification (voters) and party list (MPs), and the differences between them (shaded). Scales are 5-point. Sources: Study of MPs, 2008; and Study of Portuguese Citizens, 2008 (in Freire, Viegas and Seiceira, 2009). 
Table 2. Policy agreement between voters and MPs on the libertarian-authoritarian dimension (\%)

\begin{tabular}{|c|c|c|c|c|c|c|c|c|c|c|c|c|c|c|c|}
\hline \multirow{2}{*}{$\begin{array}{l}\text { DIMENSION: Libertarian - } \\
\text { Authoritarian }\end{array}$} & \multicolumn{3}{|c|}{$\mathbf{B E}$} & \multirow[b]{2}{*}{ Voters } & \multirow{2}{*}{$\begin{array}{l}\text { CDU } \\
\text { MPs }\end{array}$} & \multirow[b]{2}{*}{ Diff } & \multirow[b]{2}{*}{ Voters } & \multirow{2}{*}{$\begin{array}{c}\text { PS } \\
\text { MPs }\end{array}$} & \multirow[b]{2}{*}{ Diff } & \multirow[b]{2}{*}{ Voters } & \multirow{2}{*}{$\begin{array}{l}\text { PSD } \\
\text { MPs }\end{array}$} & \multirow[b]{2}{*}{ Diff } & \multirow[b]{2}{*}{ Voters } & \multirow{2}{*}{$\begin{array}{l}\text { CDS } \\
\text { MPs }\end{array}$} & \multirow[b]{2}{*}{ Diff } \\
\hline & Voters & MPs & Diff & & & & & & & & & & & & \\
\hline $\begin{array}{l}\text { "Immigrants should be required to adapt } \\
\text { to Portuguese customs" }\end{array}$ & 64.7 & 0.0 & 64.7 & 58.2 & 0.0 & 58.2 & 58.8 & 10.9 & 47.9 & 63.8 & 27.7 & 36.1 & 64.2 & 62.5 & 1.7 \\
\hline $\begin{array}{l}\text { "Stronger measures should be taken to } \\
\text { protect the environment" }\end{array}$ & 97.0 & 100.0 & 3.0 & 94.3 & 100.0 & 5.7 & 96.2 & 100.0 & 3.8 & 97.7 & 100.0 & 2.3 & 73.2 & 100.0 & 26.8 \\
\hline $\begin{array}{l}\text { "Same-sex marriages should be prohibited } \\
\text { by law" }\end{array}$ & 28.5 & 0.0 & 28.5 & 46.7 & 0.0 & 46.7 & 66.5 & 17.3 & 49.2 & 75.3 & 53.1 & 22.2 & 86.8 & 57.1 & 29.7 \\
\hline $\begin{array}{l}\text { "People who break the law should be } \\
\text { given stiffer sentences" }\end{array}$ & 88.6 & 0.0 & 88.6 & 91.5 & 8.0 & 83.5 & 94.5 & 25.6 & 68.9 & 98.1 & 59.8 & 38.3 & 72.9 & 71.4 & 1.5 \\
\hline $\begin{array}{l}\text { "Immigrants are good for the Portuguese } \\
\text { economy" }\end{array}$ & 72.3 & 100.0 & 27.7 & 79.0 & 89.1 & 10.1 & 80.1 & 98.9 & 18.8 & 79.2 & 100.0 & 20.8 & 47.6 & 100.0 & 52.4 \\
\hline $\begin{array}{l}\text { "Women should be free to decide on } \\
\text { matters of abortion" }\end{array}$ & 94.9 & 100.0 & 5.1 & 96.4 & 89.1 & 7.3 & 90.1 & 93.3 & 3.2 & 78.7 & 54.6 & 24.1 & 90.4 & 0.0 & 90.4 \\
\hline $\begin{array}{l}\text { "Torturing a prisoner is never justified, } \\
\text { even if it might prevent a terrorist attack" }\end{array}$ & 71.9 & 100.0 & 28.1 & 87.3 & 100.0 & 12.7 & 84.3 & 89.0 & 4.7 & 82.1 & 79.0 & 3.1 & 92.2 & 71.4 & 20.8 \\
\hline Mean differences & & & 35.1 & & & 32.0 & & & 28.1 & & & 21.0 & & & 31.9 \\
\hline
\end{tabular}

Notes: Figures are the percentage of respondents who agreed (totally or partially) with the proposition, by party identification (voters) and party list (MPs), and the differences between them (shaded). Scales are 5-point. Sources: Study of MPs, 2008; and Study of Portuguese Citizens, 2008 (in Freire, Viegas and Seiceira, 2009). 
Figure 2. Mean distances between MPs and voters referring to left-right policy issues

"Politics should abstain from intervening in the economy"

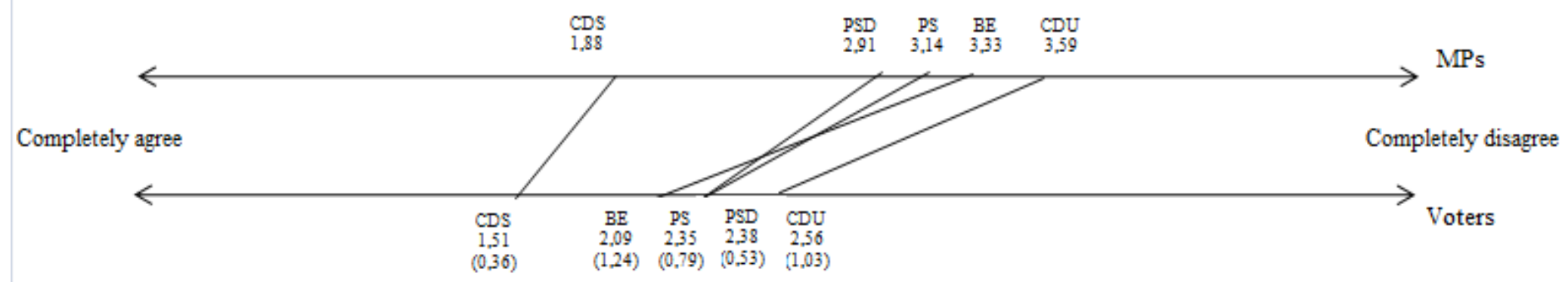

"Providing a stable social security network should be the prime goal of government"

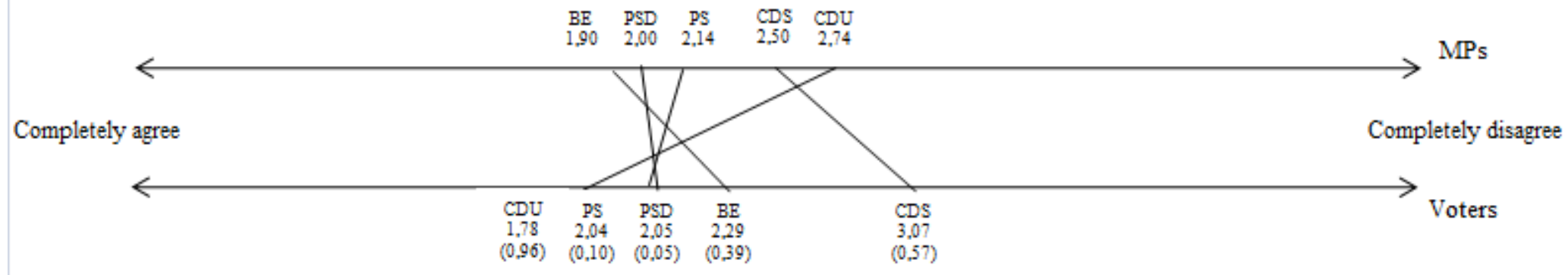

"Income and wealth should be redistributed towards ordinary people"

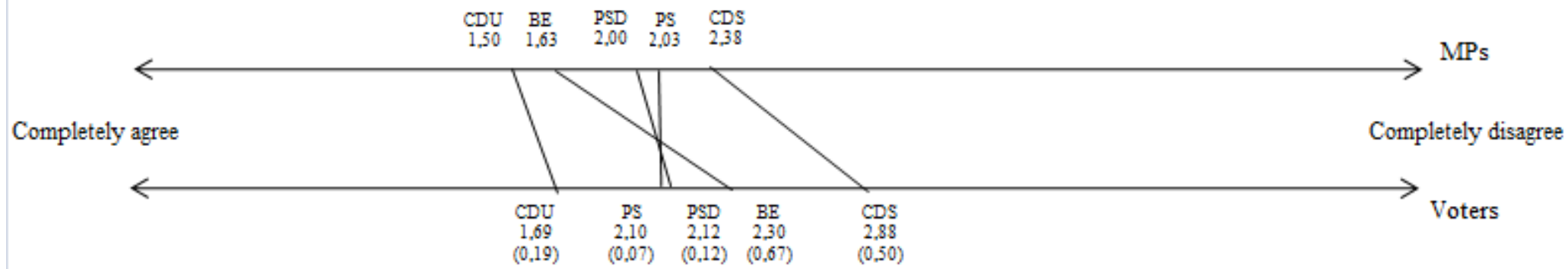




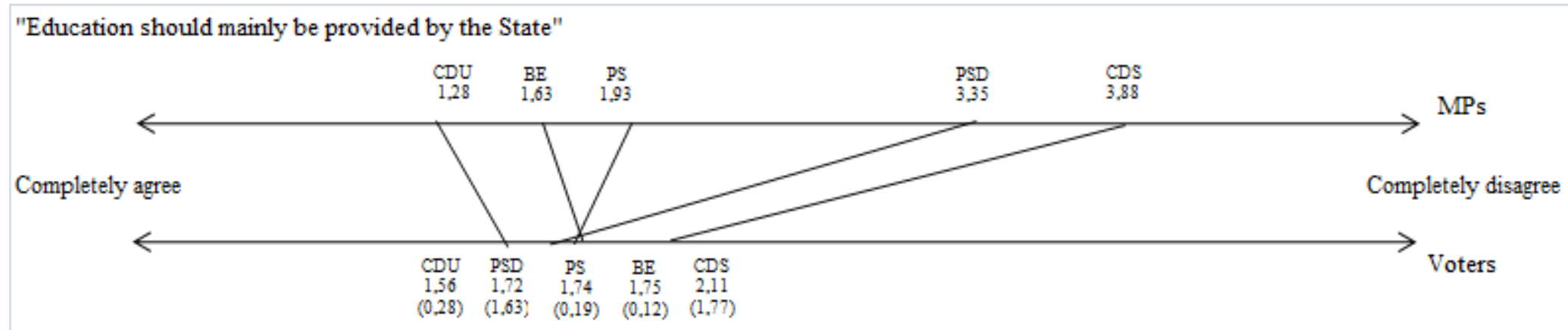

"Healthcare should be mainly provided by the State"

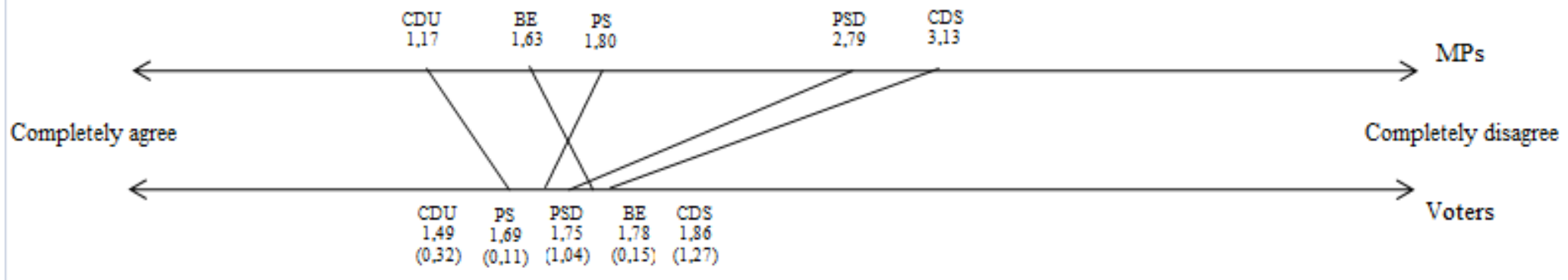

"The present levels of social protection must be kept the same even if it means an increase in taxes"

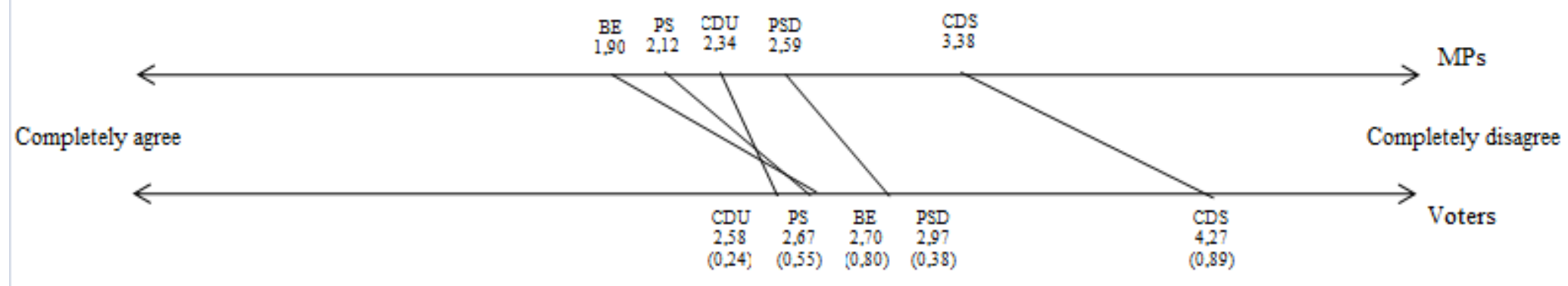


"Economic growth is more important than balacing the state budget"

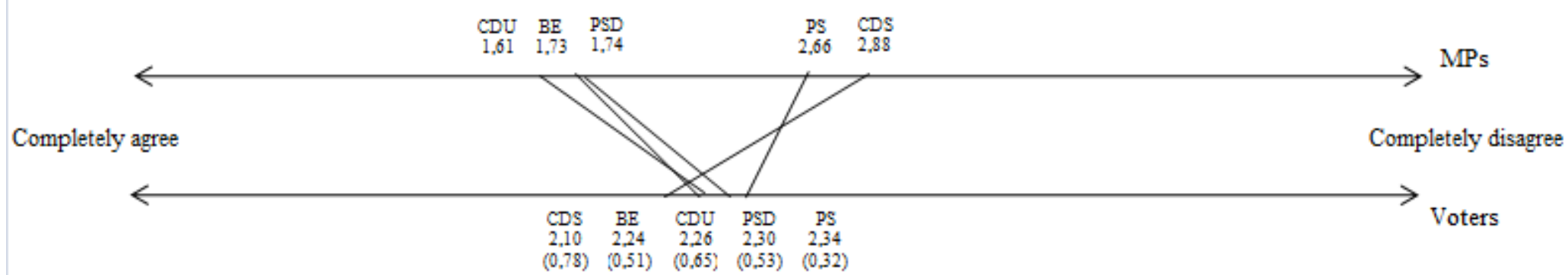


Figure 3. Mean distances between MPs and voters referring to libertarian-authoritarian policy issues "Immigrants should be required to adapt to Portuguese customs"

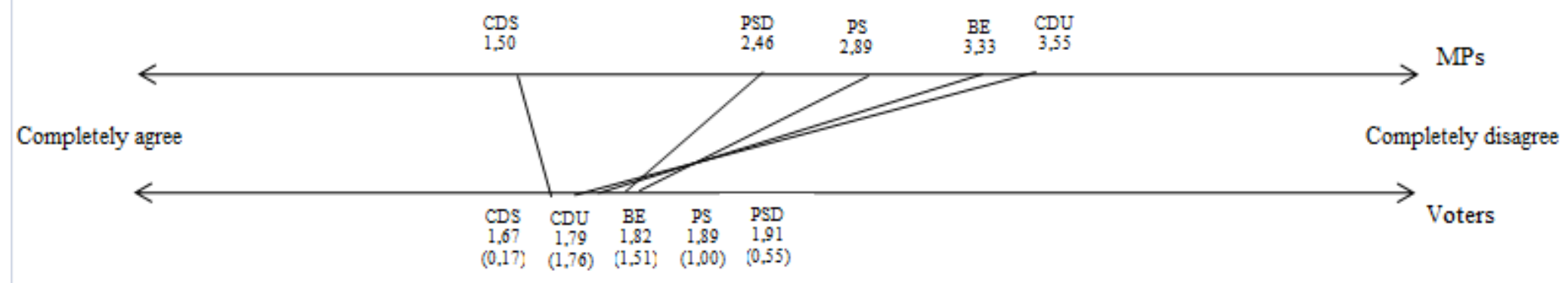

"Stronger measures should be taken to protect the environment"

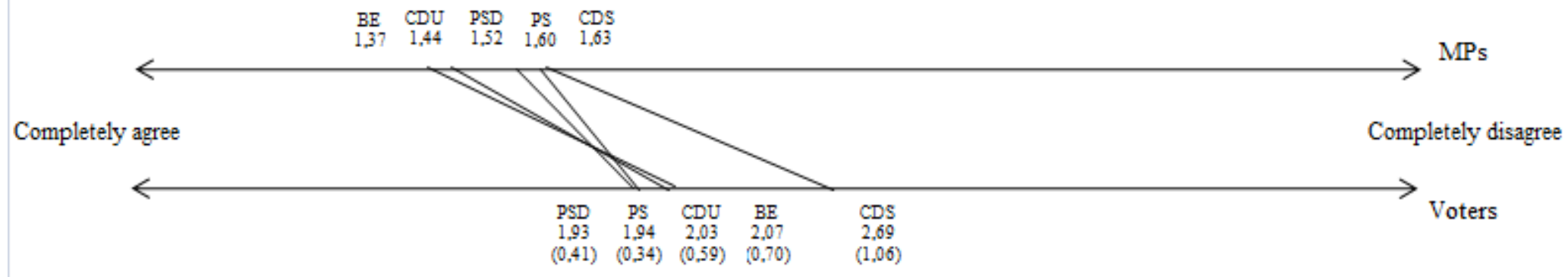

"Same-sex marriages should be prohibited by law"

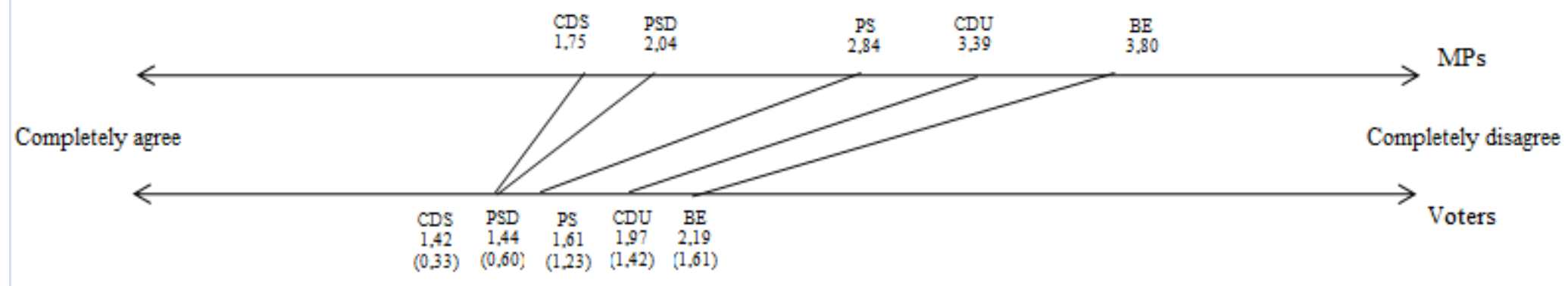




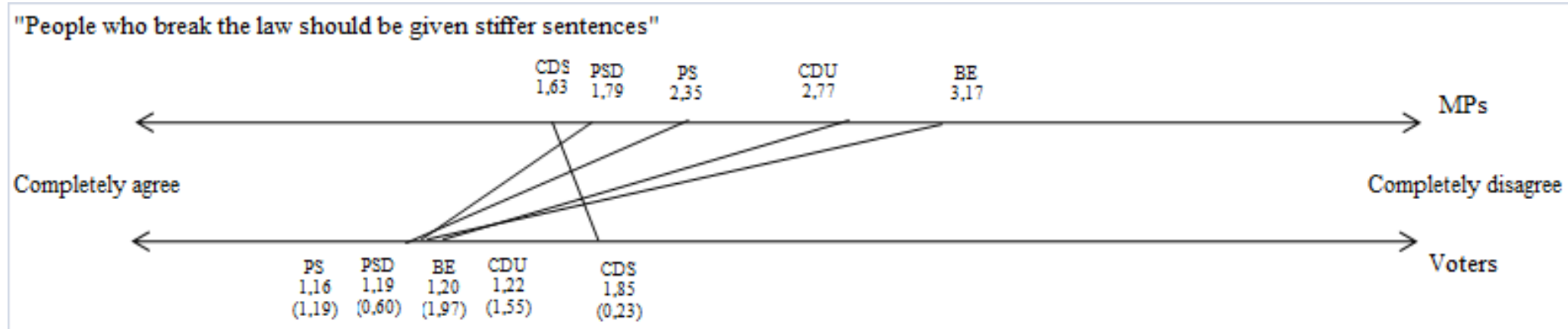

"Immigrants are good for the Portuguese economy"

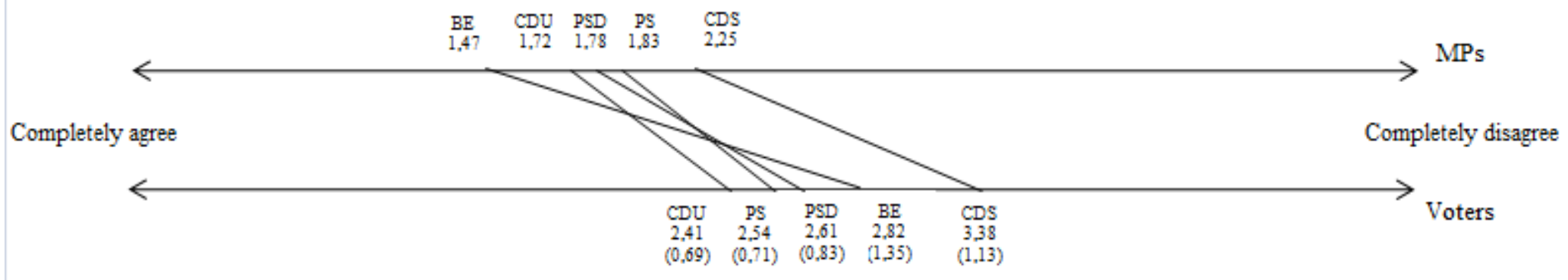

"Women should be free to decide on matters of abortion"

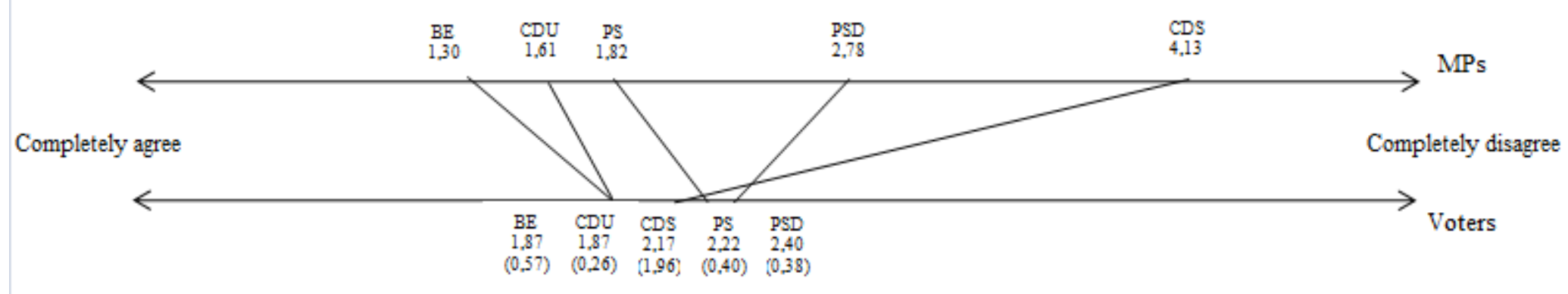


"Torturing a prisoner is never justified, even if it might prevent a terrorist attack"

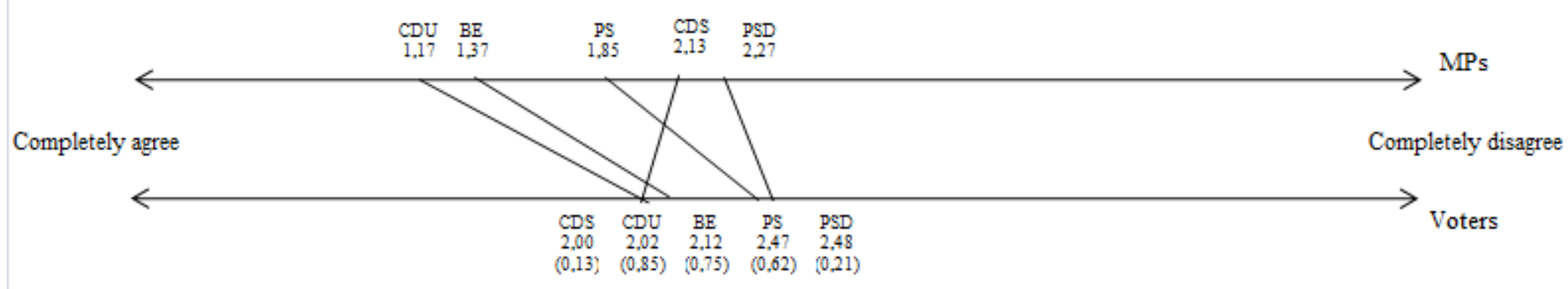


Figure 4. Mean distances between MPs and voters referring to left-right self-positioning Left-Right self-positioning

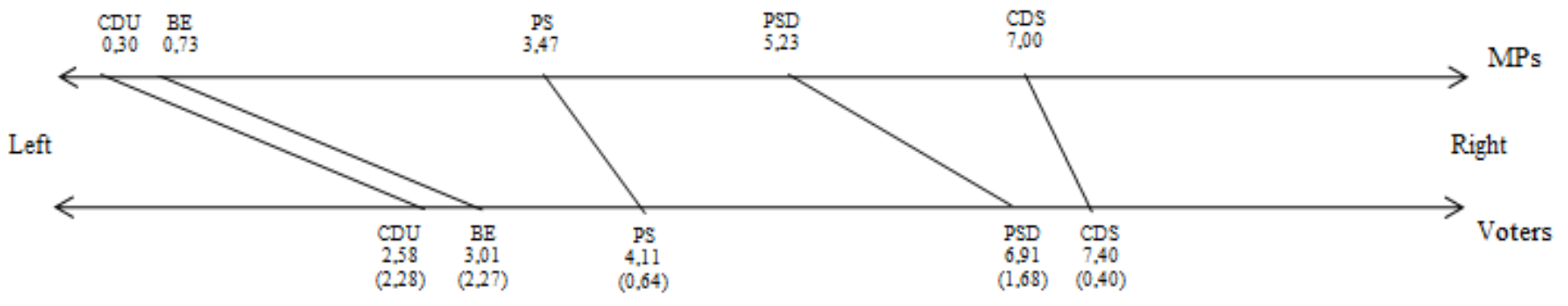

Sources: Study of MPs, 2008; and Study of Portuguese Citizens, 2008 (in Freire, Viegas and Seiceira, 2009).

Note: The scale is eleven-point: 0 , left, to 10 , right.

Figures in brackets are mean differences within party 
Figure 5. Means difference (dichotomous variable) across policy dimensions (the mean of means)

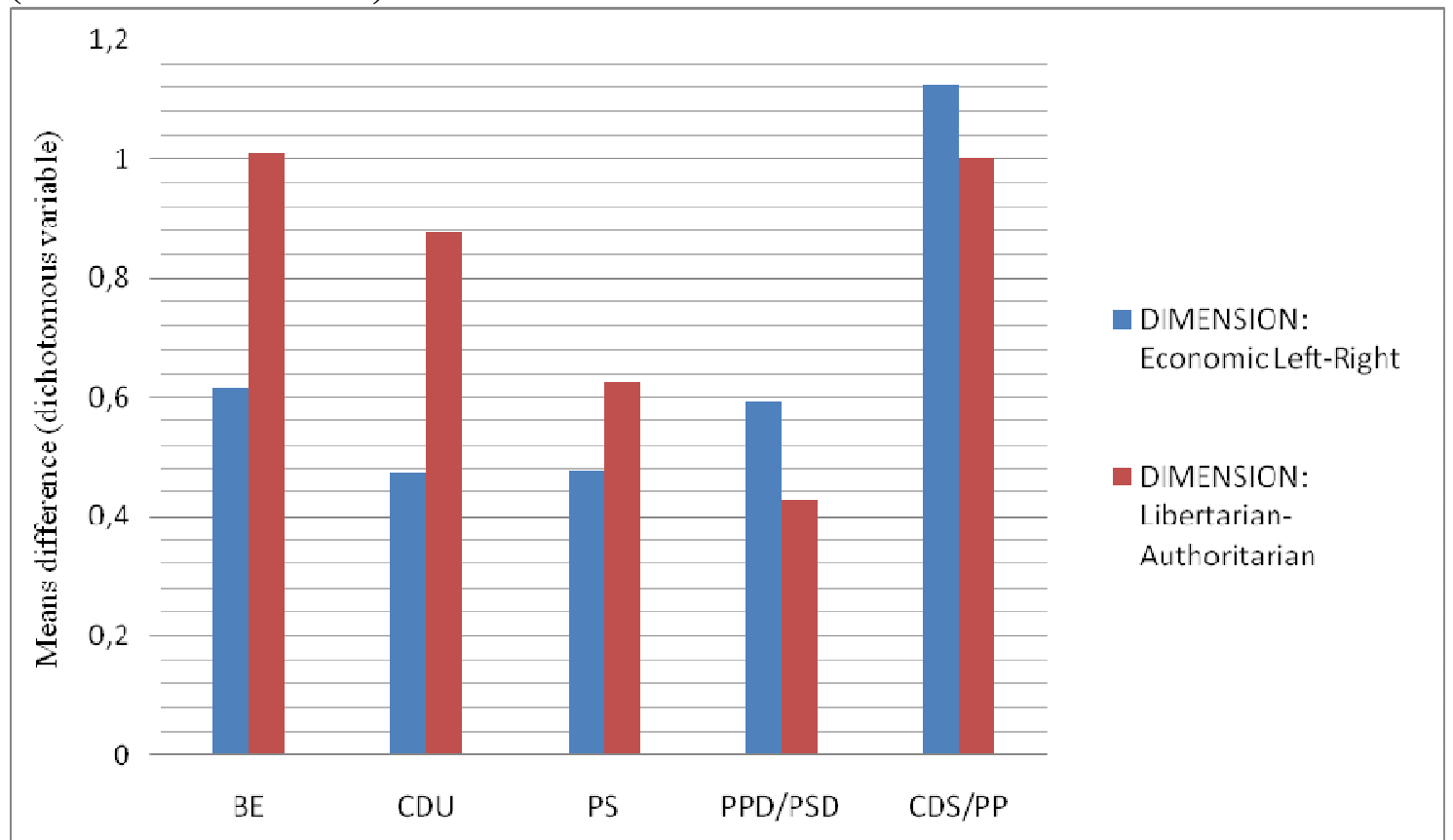

Note: The mean difference by party and dimension disregards the signs of the real differences and, therefore, all the values are entered as having positive signs. 
Table 3. Standardized mean differences across policy issues

\begin{tabular}{|c|c|c|c|c|c|c|}
\hline & & BE & CDU & PS & PPD/PSD & CDS/PP \\
\hline \multirow{7}{*}{ 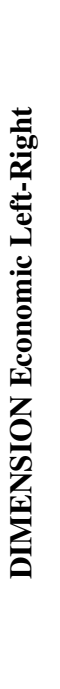 } & $\begin{array}{l}\text { "Politicians should abstain from intervening in the } \\
\text { economy" }\end{array}$ & 1.39 & 1.04 & 0.91 & 0.61 & 0.59 \\
\hline & $\begin{array}{l}\text { "Providing a stable social security network should be the } \\
\text { prime goal of government" }\end{array}$ & 0.53 & 1.35 & 0.12 & 0.06 & 0.63 \\
\hline & $\begin{array}{l}\text { "Income and wealth should be redistributed towards } \\
\text { ordinary people" }\end{array}$ & 0.84 & 0.26 & 0.09 & 0.15 & 0.56 \\
\hline & "Education should mainly be provided by the State" & 0.16 & 0.42 & 0.27 & 2.39 & 1.56 \\
\hline & "Healthcare should mainly be provided by the State" & 0.18 & 0.53 & 0.15 & 1.31 & 1.16 \\
\hline & $\begin{array}{l}\text { "The present levels of social protection must be kept the } \\
\text { same even if it means an increase in taxes" }\end{array}$ & 0.74 & 0.22 & 0.52 & 0.34 & 1.12 \\
\hline & $\begin{array}{l}\text { "Economic growth is more important than balancing the } \\
\text { state budget" }\end{array}$ & 0.54 & 0.75 & 0.41 & 0.79 & 1.55 \\
\hline \multirow{8}{*}{ 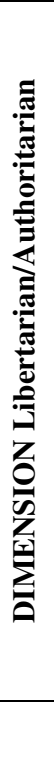 } & $\begin{array}{l}\text { "Immigrants should be required to adapt to Portuguese } \\
\text { customs" }\end{array}$ & 1.52 & 2.06 & 1.17 & 0.67 & 0.20 \\
\hline & $\begin{array}{l}\text { "Stronger measures should be taken to protect the } \\
\text { environment" }\end{array}$ & 0.72 & 0.75 & 0.46 & 0.52 & 1.47 \\
\hline & "Same-sex marriages should be prohibited by law" & 1.75 & 1.23 & 1.12 & 0.59 & 0.40 \\
\hline & $\begin{array}{l}\text { "People who break the law should be given stiffer } \\
\text { sentences" }\end{array}$ & 2.77 & 2.13 & 1.91 & 0.86 & 0.28 \\
\hline & "Immigrants are good for the Portuguese economy" & 1.38 & 0.79 & 0.87 & 0.98 & 1.24 \\
\hline & "Women should be free to decide on matters of abortion" & 0.99 & 0.34 & 0.49 & 0.38 & 2.21 \\
\hline & $\begin{array}{l}\text { "Torturing a prisoner is never justified, even if it might } \\
\text { prevent a terrorist attack" }\end{array}$ & 1.21 & 0.89 & 0.76 & 0.26 & 0.26 \\
\hline & Left-right self-positioning & 1.37 & 1.34 & 0.44 & 1.10 & 0.31 \\
\hline
\end{tabular}

Sources: Study of MPs, 2008; and Study of Portuguese Citizens, 2008 (in Freire, Viegas and Seiceira, 2009). 
Figure 6. Standardized mean differences across policy dimensions (the mean of means)

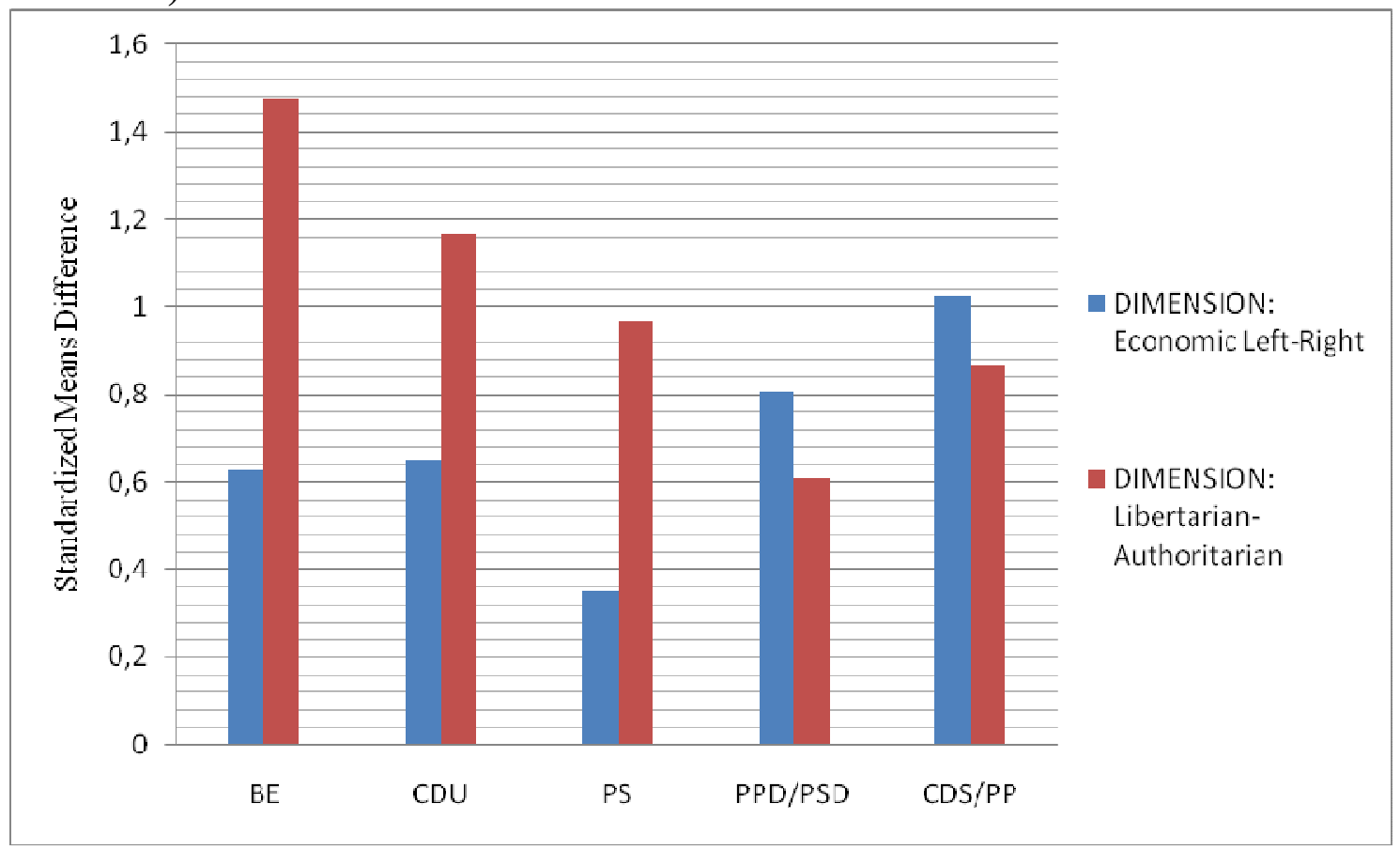


Table 4. Centrism across policy issues

\begin{tabular}{|c|c|c|c|c|c|c|}
\hline & & BE & CDU & PS & PPD/PSD & CDS/PP \\
\hline \multirow{7}{*}{ 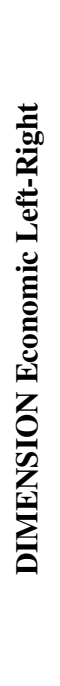 } & $\begin{array}{l}\text { "Politicians should abstain from intervening in the } \\
\text { economy" }\end{array}$ & 1.31 & 0.95 & 1.03 & 0.20 & 0.20 \\
\hline & $\begin{array}{l}\text { "Providing a stable social security network should be the } \\
\text { prime goal of government" }\end{array}$ & 0.24 & 1.07 & 0.23 & 0.19 & 0.15 \\
\hline & $\begin{array}{l}\text { "Income and wealth should be redistributed towards } \\
\text { ordinary people" }\end{array}$ & 0.63 & 0.22 & 0.24 & 0.22 & 0.11 \\
\hline & "Education should mainly be provided by the State" & 0.25 & 0.14 & 0.22 & 2.80 & 2.20 \\
\hline & "Healthcare should mainly be provided by the State" & 0.23 & 0.07 & 0.17 & 1.30 & 0.74 \\
\hline & $\begin{array}{l}\text { "The present levels of social protection must be kept the } \\
\text { same even if it means an increase in taxes" }\end{array}$ & 0.01 & 1.50 & 1.31 & 0.88 & 0.40 \\
\hline & $\begin{array}{l}\text { "Economic growth is more important than balancing the } \\
\text { state budget" }\end{array}$ & 0.23 & 0.49 & 0.21 & 0.46 & 0.79 \\
\hline \multirow{8}{*}{ 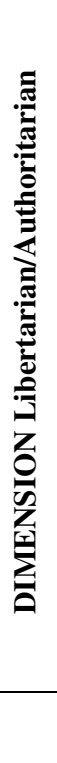 } & $\begin{array}{l}\text { "Immigrants should be required to adapt to Portuguese } \\
\text { customs" }\end{array}$ & 0.19 & 3.09 & 1.39 & 0.74 & 0.18 \\
\hline & $\begin{array}{l}\text { "Stronger measures should be taken to protect the } \\
\text { environment" }\end{array}$ & 0.46 & 0.58 & 0.40 & 0.42 & 0.79 \\
\hline & "Same-sex marriages should be prohibited by law" & 2.99 & 1.53 & 0.97 & 0.13 & 1.27 \\
\hline & $\begin{array}{l}\text { "People who break the law should be given stiffer } \\
\text { sentences" }\end{array}$ & 3.70 & 2.61 & 1.60 & 0.64 & 0.18 \\
\hline & "Immigrants are good for the Portuguese economy" & 1.08 & 0.38 & 0.23 & 0.70 & 0.67 \\
\hline & "Women should be free to decide on matters of abortion" & 0.59 & 0.33 & 0.30 & 0.26 & 2.60 \\
\hline & $\begin{array}{l}\text { "Torturing a prisoner is never justified, even if it might } \\
\text { prevent a terrorist attack" }\end{array}$ & 0.93 & 0.93 & 0.44 & 0.03 & 0.18 \\
\hline & Left-right self-positioning & 1.76 & 2.58 & 1.49 & 0.97 & 6.87 \\
\hline
\end{tabular}


Figure 7. Centrism across policy dimensions (the mean of centrism)

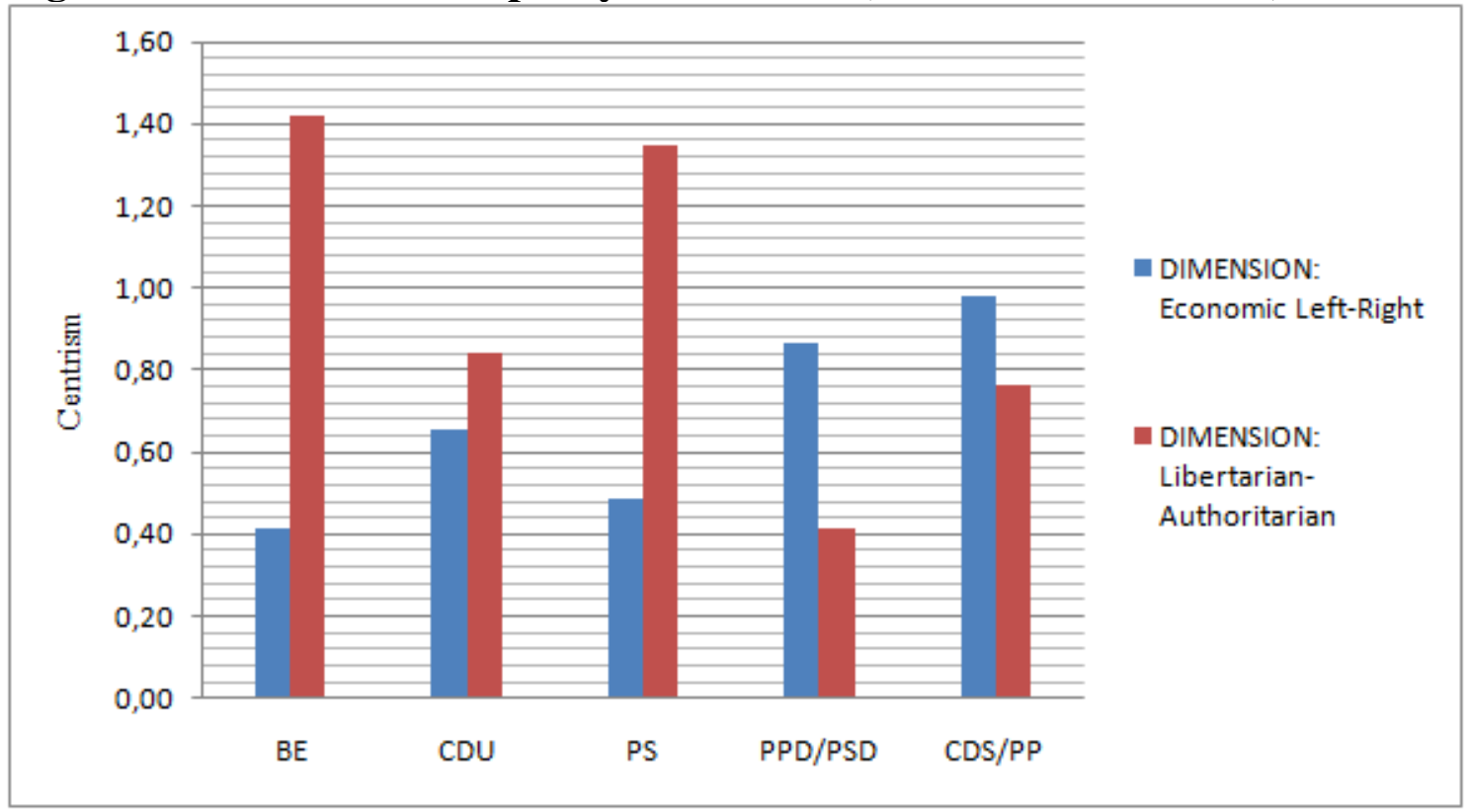


${ }^{1}$ Because our study concerns the assessment of collective congruence, although correlation and regression analysis are advocated by many authors (e.g. Achen, 1978; Dalton, 1985; Converse and Pierce, 1986), they are not used here.

${ }^{2}$ Although very close to Achen's suggestion (1978), our measure of centrism considers the median position of citizens instead of the mean in order to overcome the bias that the latter might introduce if the distribution is removed from the normal, which is potentially the case when it comes to citizens (as per Huber and Powell, 1994: 295-296; for support for this option, also see: Converse and Pierce, 1986: 511516; Powell, 2000: 94).

${ }^{3}$ In order to split the voters into parties, we used party identification instead of voting intention to increase the number of cases (the number of "party identifiers" was larger than those willing to participate in a possible election). Having said this, using voting intention produces the same results.

${ }^{4}$ Question: "People hold different views on political issues. What do you think of the following?" (scale: completely disagree / completely agree).

${ }^{5}$ These two scales were constructed using both theoretical guidance and reliability scaling (Chronbach's Alpha). Both procedures revealed that the scales are valid and reliable for both MPs and voters, although with some variation (less reliability for the new politics issues). Space limitations mean we cannot present this information here, but it can be furnished upon request.

${ }^{6}$ The effective sample sizes per political party for the 14 policy issues and left-right position are:

\begin{tabular}{lccc}
\hline & $\begin{array}{c}\text { No. MPs in } \\
\text { Parliament (2009) }\end{array}$ & $\begin{array}{c}\text { Sample of } \\
\text { MPs }\end{array}$ & $\begin{array}{c}\text { Sample of } \\
\text { voters }\end{array}$ \\
\hline BE & 8 & $3-4$ & 24 \\
\hline CDU & 14 & $7-8$ & $55-69$ \\
\hline PS & 121 & $74-76$ & $174-326$ \\
\hline PPD/PSD & 75 & $43-45$ & $193-251$ \\
\hline CDS/PP & 12 & 8 & 13 \\
\hline
\end{tabular}

${ }^{7}$ The figures are the sum of: "completely agree" plus "agree"; and "completely disagree" plus "disagree". 